\title{
Extracellular superoxide dismutase in the airways of transgenic mice reduces inflammation and attenuates lung toxicity following hyperoxia
}

\author{
Rodney J. Folz, ${ }^{1,2}$ Amir M. Abushamaa, ${ }^{1}$ and Hagir B. Suliman ${ }^{1}$ \\ ${ }^{1}$ Department of Medicine, and \\ ${ }^{2}$ Department of Cell Biology, Division of Pulmonary and Critical Care Medicine, Duke University Medical Center, \\ Durham, North Carolina 27710, USA \\ Address correspondence to: Rodney J. Folz, Box 2620, Room 331 MSRB, Duke University Medical Center, Durham, \\ North Carolina 27710, USA. Phone: (919) 684-3539; Fax: (919) 681-8936; E-mail: rodney.folz@duke.edu \\ Received for publication April 23, 1998, and accepted in revised form February 11, 1999.
}

\begin{abstract}
Extracellular superoxide dismutase (EC-SOD, or SOD3) is the major extracellular antioxidant enzyme in the lung. To study the biologic role of EC-SOD in hyperoxic-induced pulmonary disease, we created transgenic (Tg) mice that specifically target overexpression of human EC-SOD (hEC-SOD) to alveolar type II and nonciliated bronchial epithelial cells. Mice heterozygous for the hEC-SOD transgene showed threefold higher EC-SOD levels in the lung compared with wild-type (Wt) littermate controls. A significant amount of hEC-SOD was present in the epithelial lining fluid layer. Both $\mathrm{Tg}$ and Wt mice were exposed to normobaric hyperoxia (>99\% oxygen) for 48, 72, and 84 hours. Mice overexpressing hECSOD in the airways attenuated the hyperoxic lung injury response, showed decreased morphologic evidence of lung damage, had reduced numbers of recruited inflammatory cells, and had a reduced lung wet/dry ratio. To evaluate whether reduced numbers of neutrophil infiltration were directly responsible for the tolerance to oxygen toxicity observed in the Tg mice, we made Wt and $\mathrm{Tg}$ mice neutropenic using anti-neutrophil antibodies and subsequently exposed them to 72 hours of hyperoxia. Both Wt and Tg neutrophil-depleted (ND) mice have less severe lung injury compared with non-ND animals, thus providing direct evidence that neutrophils recruited to the lung during hyperoxia play a distinct role in the resultant acute lung injury. We conclude that oxidative and inflammatory processes in the extracellular lung compartment contribute to hyperoxic-induced lung damage and that overexpression of hEC-SOD mediates a protective response to hyperoxia, at least in part, by attenuating the neutrophil inflammatory response.
\end{abstract}

J. Clin. Invest. 103:1055-1066 (1999).

\section{Introduction}

All forms of aerobic life face the threat of oxidation from molecular oxygen $\left(\mathrm{O}_{2}\right)$. Conceivably to cope with various reactive oxygen species (ROS), different classes of enzymatic and nonenzymatic antioxidants have evolved. Antioxidants function by preventing the accumulation of toxic levels of oxygen-derived free radicals, which can damage the cells by modifying proteins, lipids, and DNA. Yet because $\mathrm{O}_{2}$ is vital to human life, hyperoxic therapy is sometimes used in the care and management of critically ill patients who cannot breathe efficiently. Such patients often require supraphysiological concentrations of $\mathrm{O}_{2}(>21 \%)$ to maintain organ viability and homeostasis (1). Ironically, hyperoxia can be toxic to normal cells and organisms, and in particular, mammalian lungs appear to be sensitive to oxidative injury (2). The lungs typically receive the highest $\mathrm{O}_{2}$ exposure (1).

The pathogenesis of $\mathrm{O}_{2}$-induced lung injury is not completely understood. Hyperoxia is associated with increased levels of ROS (3), which is reflected by the accumulation of oxidatively damaged cellular macromolecules and chromosomal breakage. However, $\mathrm{O}_{2}$ may damage lung cells directly via generation of ROS (4) and indirectly via the action of inflammatory cells and inflammatory mediators (5), which may, in turn, over- whelm the cellular antioxidant defenses and lead to the accumulation of toxic levels of ROS. In cultured transformed alveolar epithelial cells, exposure to hyperoxia $\left(95 \% \mathrm{O}_{2}\right)$ is also associated with cell-cycle arrest at G2 (6) and inactivation of aconitase (7). Under certain conditions, exposure to $>40 \% \mathrm{O}_{2}$ can be lethal to cells (8).

Superoxide dismutases (SODs) are key antioxidant enzymes in the metabolism of oxygen-free radicals. They catalyze the dismutation of the superoxide anion radical to oxygen and hydrogen peroxide. Generation and/or removal of superoxides has been observed to play significant roles in a variety of critical homeostatic mechanisms at both the cellular and organismic levels. Because biologic macromolecules are a likely target for the damaging action of abundant oxygen radicals, studying the role that these enzymes play in preventing the damage associated with ROS is of great biologic and clinical importance. For example, previous studies have shown that transgenic ( $\mathrm{Tg}$ ) mice that overexpress copper/zinc SOD (CuZn-SOD) or manganese SOD (Mn-SOD), antioxidant enzymes that are exclusively intracellular, are partly protected when exposed to hyperoxic injury $(9,10)$.

Extracellular superoxide dismutase (EC-SOD), or SOD3, is the dominant antioxidant enzyme found in a variety of extracellular compartments (11). The human 


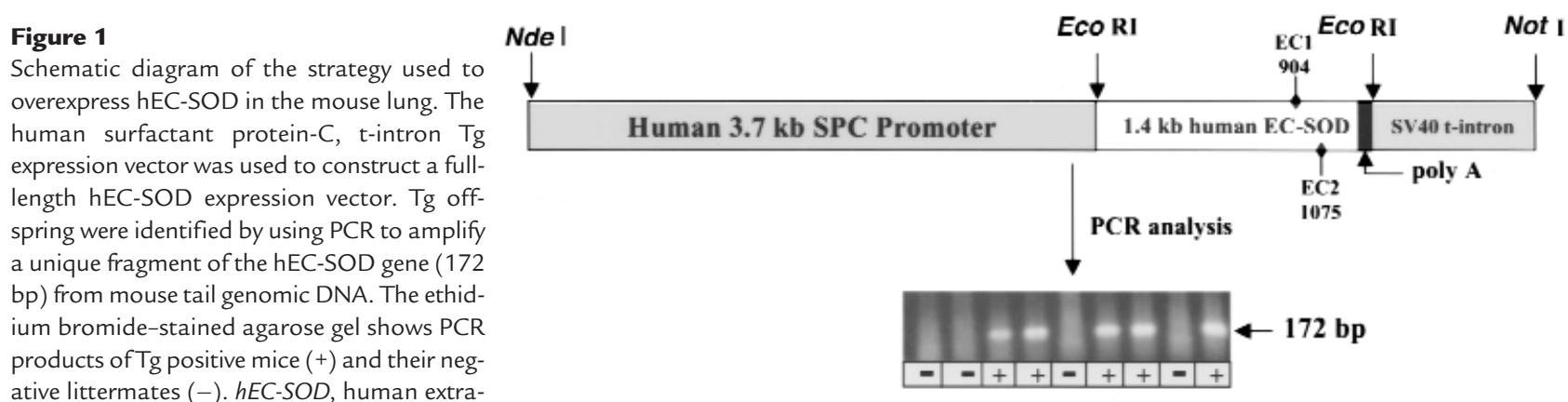

EC-SOD (hEC-SOD) and mouse EC-SOD are homotetrameric proteins with a relative molecular mass of 135,000 , whereas the rat enzyme is dimeric $(12,13)$. ECSOD is secreted into the extracellular spaces, and in the lung it is expressed primarily by the alveolar type II pneumocytes (14). EC-SOD is glycosylated and exhibits affinity for sulfated polysaccharides, such as heparin or heparan sulfate. Although detectable in blood plasma, EC-SOD is mostly bound to the extracellular matrix (15). It is well documented that under conditions of hyperoxia, the lungs are exposed to oxidative stress, leading to both endothelial and epithelial injury (16). Recently, mice totally lacking EC-SOD have been created, and they show evidence for increased sensitivity to hyperoxia exposure (17). It is difficult, however, to determine the site-specific effects of this knockout to hyperoxia because all cell types and tissues lack ECSOD. To begin to explore the role that airway and alveolar extracellular antioxidants play in hyperoxia exposure, we overexpressed hEC-SOD in a highly specific fashion in airway and alveolar epithelial cells. By doing so, we have found that these animals have an increased tolerance to hyperoxia.

\section{Methods}

Generation of bEC-SOD Tg mice. The human surfactant protein-C (SP-C), t-intron transgene expression vector was kindly obtained from J.R. Wispe (Children's Hospital Medical Center, Cincinnati, Ohio, USA). The construction of this vector has been described previously (10). Briefly, this vector contains the $3.7-\mathrm{kb}$ promoter region of the SP-C gene, including the TATAA box, and directs transgene expression to alveolar type II and nonciliated distal bronchial epithelial cells (18). A full-length hEC-SOD cDNA (1.4 kb) encoding an 18-amino acid signal peptide as well as the 222-amino acid mature polypeptide (19) was ligated into the EcoRI site of the expression vector polylinker (Figure 1). Plasmid DNA containing the sense-strand transgene vector was purified, linearized by restriction endonuclease digestion using NotI and NdeI, and an 6-kb linear fragment (containing the SP$\mathrm{C}$ promoter, hEC-SOD transgene, and SV40 t-intron and poly A signal) was isolated after agarose gel electrophoresis. Purified linearized DNA at $2 \mu \mathrm{g} / \mathrm{ml}$ in $40 \mathrm{mM}$ Tris - acetate, $2 \mathrm{mM}$ $\mathrm{Na}_{2}$ EDTA $2 \mathrm{H}_{2} \mathrm{O}(\mathrm{pH}$ 8.5) was injected into the pronuclei of fertilized eggs isolated from mice [(B6×SJL)F1 $\times(\mathrm{B} 6 \times \mathrm{SJL}) \mathrm{F} 1]$ obtained from The Jackson Laboratory (Bar Harbor, Maine, USA). Eggs surviving microinjection were implanted into the oviducts of pseudopregnant foster mothers $(\mathrm{B} 6 \times \mathrm{SJL}) \mathrm{F} 1$.

$\mathrm{Tg}$ founders were bred into the strain $\mathrm{B} 6 \mathrm{C} 3$ to obtain sixthgeneration animals and were identified by PCR analysis of tail DNA using the forward primer EC1 (5'-AGACACCTTC-
CACTCTGAGG-3') and the reverse primer EC2 (5'-GTTTCGGTACAAATGGAGGC-3'). The PCR was performed using a Perkin-Elmer 9600 thermal cycler and a final sample volume of $25 \mu \mathrm{l}$ under the following conditions: EC1 and EC2 (10 pmol each), tail DNA (350 ng), $200 \mu \mathrm{M}$ of dATP, dTTP, dCTP, dGTP, $2.5 \mathrm{mM}$ of $\mathrm{MgCl}_{2}$, Taq polymerase (0.625 U), and $1 \times$ PCR buffer (50 mM KCL, $10 \mathrm{mM}$ Tris-HCl [pH 8.3]). After heating the sample to $94^{\circ} \mathrm{C}$ for $3 \mathrm{~min}$, the sample underwent 32 cycles of three-step PCR $\left(94^{\circ} \mathrm{C}\right.$ for $40 \mathrm{~s}$, followed by $57^{\circ} \mathrm{C}$ for $30 \mathrm{~s}$, followed by $72^{\circ} \mathrm{C}$ for $45 \mathrm{~s}$ ).

Measurement of lung antioxidant levels. For EC-SOD determinations, tissues from three mice in each group were weighed and homogenized in 10 volumes of ice-cold $50 \mathrm{mM}$ potassium phosphate buffer ( $\mathrm{pH} 7.4$ ) with $0.3 \mathrm{M} \mathrm{KBr}$, and a set of antiproteolytic agents $(0.5 \mathrm{mM}$ phenyl methylsulfonyl fluoride, $3 \mathrm{mM}$ diethylentriaminepentaacetic acid, $90 \mathrm{mg}$ of aprotinin per liter, $10 \mathrm{mg}$ of pepstatin per liter, $10 \mathrm{mg}$ of chymostatin per liter, and $10 \mathrm{mg}$ of leupeptin per liter). The homogenate was then sonicated, and separation of EC-SOD from CuZn-SOD and Mn-SOD was accomplished by passage over a concanavalin A-Sepharose column as described previously (20). We have found the recovery of EC-SOD to be $>98 \%$. The EC-SOD activity was measured by inhibition of cytochrome $c$ reduction at $\mathrm{pH} 10$ as described (21). One unit of SOD activity is defined as the enzyme activity needed to inhibit a $50 \%$ reduction in cytochrome $c$.

The activities of CuZn-SOD and Mn-SOD were determined by measuring the inhibition of xanthine plus xanthine oxidase-mediated cytochrome $c$ reduction at $\mathrm{pH} 7.8$ (21). To distinguish the contributions of CuZn-SOD and Mn-SOD to the total superoxide dismutase activity, $1 \mathrm{mM} \mathrm{KCN}$ was used to inhibit the activity of CuZn-SOD.

For catalase activity, the tissues were homogenized in $1.0 \%$ Triton X-100 using a variable-speed tissue tearer (Brinkmann Instruments Inc., Westbury, New York, USA) at 20,000 $\mathrm{g}$ for 1 min on ice. The resulting homogenate was centrifuged at $10,000 \mathrm{~g}$ at $4^{\circ} \mathrm{C}$ for $20 \mathrm{~min}$. The enzyme activity was determined by the method described by Aebi (22). Briefly, the supernatant was diluted with 1.5 volumes of the assay buffer containing 50 $\mathrm{mM} \mathrm{K}_{2} \mathrm{HPO}_{4}$ and $50 \mathrm{mM} \mathrm{NaH}_{2} \mathrm{PO}_{4}$ at $\mathrm{pH}$ 7.0. The reaction was initiated by adding $1.0 \mathrm{ml}$ of $30 \mathrm{mM} \mathrm{H}_{2} \mathrm{O}_{2}$, and the change in absorbance at $240 \mathrm{~nm}$ was measured at $25^{\circ} \mathrm{C}$ for $1 \mathrm{~min}$. A portion of the remaining sample was used for protein determination. The specific activity of catalase is defined as micromoles of $\mathrm{H}_{2} \mathrm{O}_{2}$ consumption per minute per milligram of tissue protein. Calculation of $\mathrm{H}_{2} \mathrm{O}_{2}$ concentration was made using a millimolar extinction coefficient for $\mathrm{H}_{2} \mathrm{O}_{2}$ of 0.0394 (22).

The glutathione peroxidase (GPx) activities in tissue homogenates and bronchoalveolar lavage fluid (BALF) were determined by the indirect, coupled test procedure (23). Briefly, the oxidized glutathione (GSSG) produced during GPx enzyme reaction was immediately reduced by the exogenous addition of 
nicotinamide adenine dinucleotide phosphate (NADPH) and glutathione reductase. Therefore, the rate of NADPH consumption was monitored as a measurement for the rate of GSSG formation. The enzyme reaction was conducted in a buffer containing $20 \mathrm{mM}$ potassium phosphate ( $\mathrm{pH}$ 7.0), $0.6 \mathrm{mM}$ EDTA, $0.15 \mathrm{mM}$ NADPH, $4 \mathrm{U}$ of glutathione reductase (Sigma Chemical Co., St. Louis, Missouri, USA), $2 \mathrm{mM}$ reduced glutathione (GSH), $1 \mathrm{mM}$ sodium azide, and $0.1 \mathrm{mM} \mathrm{H}_{2} \mathrm{O}_{2}$ at $25^{\circ} \mathrm{C}$. The rate of decrease in absorption of NADPH at $340 \mathrm{~nm}$ was measured. The GPx activity is defined by nanomoles of NADPH consumption per minute per milligram of tissue protein at $2 \mathrm{mM} \mathrm{GSH}$. Consumption of NADPH was calculated using a millimolar extinction coefficient for NADPH of 6.22 (23).

Immunobistochemistry. The distribution of hEC-SOD expression in the $\mathrm{Tg}$ mice lungs was evaluated with light microscopic immunohistochemistry using a biotin/streptavidin-horseradish peroxidase labeling technique. Briefly, paraffin sections were rehydrated with phosphate buffer containing $0.1 \%$ Tween20 (PBS-T) and blocked by immersion in $2.0 \%$ normal goat serum or $2.5 \%$ nonfat milk. For EC-SOD immunostaining, the tissue sections were incubated with a 1:1,000 dilution of the primary antibody (WT474) for $2 \mathrm{~h}$ at $37^{\circ} \mathrm{C}$. The sections were washed with PBS-T before incubation with the goat anti-rabbit IgG secondary antibody for $1 \mathrm{~h}$ at $37^{\circ} \mathrm{C}$, washed again in PBS-T, and detected with peroxidase using the Vector standard kit as recommended by the manufacturer (Vector Laboratories, Burlingame, California, USA). Preimmune rabbit serum and preabsorbed antibodies, prepared by passing the WT474 antibody through the hEC-SOD peptide-bound column, were used as controls for the EC-SOD immunostaining.

Nentrophil depletion. hEC-SOD Tg and Wt littermate mice (6-8 weeks old) were randomly assigned into four groups (two $\mathrm{Tg}$ groups and two Wt groups containing 18 mice in each group). One group each of Tg and Wt animals were neutrophil-depleted (ND) by administering polyclonal rabbit anti-mouse neutrophil antibody (24) (Accurate Chemical \& Scientific Corp., Westbury, New York, USA). The anti-neutrophil antibody was administered by intraperitoneal injections ( $0.2 \mathrm{ml}$ of $1: 15$ dilution in PBS) for three consecutive doses every $12 \mathrm{~h}$, followed by a fourth dose after $50 \mathrm{~h}$. Concurrently, mice from the third and fourth groups were injected with vehicle only (PBS) and used as controls for the neutropenic animals. These mice were exposed to hyperoxia on the fourth day after confirming agranulocytosis by Wright Giemsa-stained buffy coat from peripheral blood smears and total leukocyte counts. The effective neutropenia was $80-86 \%$, with the total neutrophil count decreasing from a range of $302-540 \mathrm{cell} / \mathrm{mm}^{3}$ in the PBStreated animals to $54-80 \mathrm{cell} / \mathrm{mm}^{3}$ in the anti-neutrophil antibody-treated group $(P<0.05)$.

Exposure to normobaric byperoxia. Wt and Tg mice strain 32 (6-8 weeks old) were randomly assigned and housed in a small-animal, airtight plexiglas chamber. Both male and female mice were equally represented in each experimental cohort. These mice were exposed continuously to hyperoxic conditions using an oxygen flow rate of $10 \mathrm{l} / \mathrm{min}$. The concentration of $\mathrm{O}_{2}$ in the chambers was monitored continuously with a Servomax $\mathrm{O}_{2}$ analyzer (model 572; Sybron, Norwood, Massachusetts, USA) and maintained to $>99 \%$, except for $10 \mathrm{~min} /$ day when the cages were opened to room air during periods of cleaning and general maintenance. The $\mathrm{CO}_{2}$ concentration was held below $0.1 \%$, the temperature was controlled between $25^{\circ} \mathrm{C}$ and $26^{\circ} \mathrm{C}$, and the humidity was $<40 \%$. The mice were provided ad libitum access to food and water and were observed continuously for signs of discomfort and $\mathrm{O}_{2}$ toxicity. Mice used in this experiment were sacrificed at 48, 72, and $84 \mathrm{~h}$ after exposure. Control $\mathrm{Tg}$ and $\mathrm{Wt}$ mice were kept in identical chambers and exposed only to room air. ND Tg and Wt animals, as well as their vehicle-only treated controls, were exposed to $>99 \%$ oxygen for only 72 hours as already described here. In addition, a similar set of ND animals

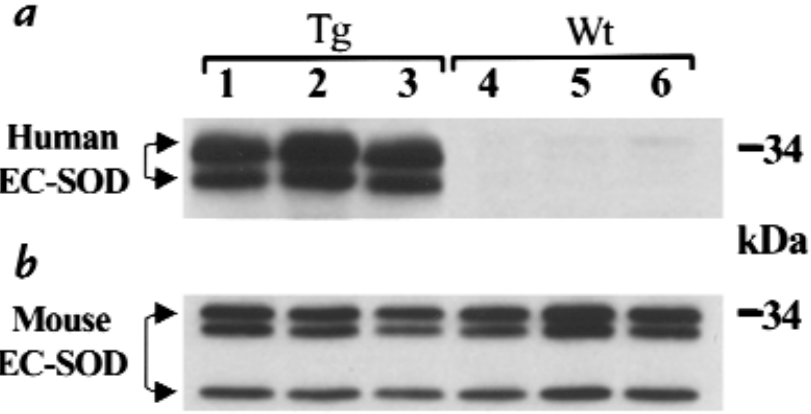

Figure 2

Western blot analysis of human and mouse EC-SOD from the lungs of wild-type $(W t)$ and hEC-SOD transgenic $(T g)$ mice. Lung protein homogenates from $\mathrm{Wt}$ and $\mathrm{Tg}$ mice were electrophoresed in $12.5 \%$ SDS-polyacrylamide gel. The separated proteins were transferred to Immobilon-P and probed with the anti-hEC-SOD antibodies (WT474) or with anti-mouse EC-SOD (SS618) polyclonal antibodies. (a) Western blot of total lung protein $(10 \mu \mathrm{g})$ probed with WT474. Lanes 1, 2, and 3 reflect lung homogenate from three independent $\mathrm{Tg}$ mice, whereas lanes 4,5 , and 6 are from Wt littermate controls. (b) An identical Western blot as in a was probed with SS618. Of note, hEC-SOD typically shows two bands with the lower-molecular-weight species representing a truncated $\mathrm{COOH}$-terminus. Mouse EC-SOD typically shows three bands, with the lower two also representing $\mathrm{COOH}$-terminal truncations (14).

were kept in identical chambers exposed only to room air.

Bronchoalveolar lavage. Mice were anesthetized by intraperitoneal injection of pentobarbital $(50 \mu \mathrm{g} / \mathrm{g})$. After the onset of adequate anesthesia, the trachea was exposed and a 20-gauge needle was used to puncture the trachea and was replaced with a 21-gauge blunt needle. A silk ligature was fastened around the trachea to secure the needle. Bronchoalveolar lavage (BAL) was performed with $1 \mathrm{ml}$ PBS using a $1-\mathrm{ml}$ syringe and repeated once. The collected fluid was immediately processed as follows. BALF $(300 \mu \mathrm{l})$ was cytocentrifuged and stained with a leukostat stain kit (Fisher Scientific Co., Pittsburgh, Pennsylvania, USA). A minimum of 300 cells were subsequently counted to obtain a differential cell count. Cellular BALF (30-50 $\mu \mathrm{l})$ was stained with trypan blue, and the total cell count was manually obtained using a Neubauer hemocytometer (Reichert, Buffalo, New York, USA). The remaining BALF was centrifuged at $1,800 \mathrm{~g}$ for $5 \mathrm{~min}$ at $4^{\circ} \mathrm{C}$, and the supernatant was decanted and recentrifuged a second time at $12,000 \mathrm{~g}$ for $10 \mathrm{~min}$ at $4^{\circ} \mathrm{C}$. The supernatant was collected and saved at $-80^{\circ} \mathrm{C}$ for further analysis, and the pelleted cells were snap frozen in liquid nitrogen and stored at $-80^{\circ} \mathrm{C}$.

Lung edema or wet/dry weight ratio. After euthanasia of mice, the lungs were surgically dissected free from the heart, trachea, and main bronchi and removed. Each lung was blotted dry, weighed, and then dried to a constant weight by placing the lung specimen in a vacuum oven at $60^{\circ} \mathrm{C}$ for $48 \mathrm{~h}$. The ratio of the wet lung to the dry lung was calculated to assess tissue edema.

Lung permeability. The permeability and/or cellular injury of the lung was determined by measuring the BALF lactate dehydrogenase (LDH) spectrophotometrically using the LDH assay kit (Sigma Chemical Co.) and total protein using the BCA assay (Pierce Chemical Co., Rockford, Illinois, USA) according to directions by the manufacturers.

Lipid peroxidation as measured by malondialdebyde concentration. Lipid peroxidation in the form of malondialdehyde (MDA) was measured according to the procedure of Wong et al. (25). Briefly, $100 \mu$ l of BALF or lung homogenate sample was treated with 150 $\mu \mathrm{l}$ of $0.44 \mathrm{M}$ phosphoric acid and $50 \mu \mathrm{l}$ of $0.6 \%$ thiobarbituric acid. The mixture was heated at $100^{\circ} \mathrm{C}$ in a heating block for $1 \mathrm{~h}$. 


\section{Figure 3}

Immunohistochemical staining of mouse lung tissues using rabbit anti-hEC-SOD antibodies. (a) Tg mouse lung demonstrating staining of type II cells with anti-hEC-SOD antisera. (b) Tg mouse showing hEC-SOD staining of the nonciliated bronchoepithelial lining cells. (c) Wt mouse lung did not stain with the hEC-SOD antibody. (d) Normal Wt mouse bronchoepithelial lining cells did not stain with anti-hEC-SOD antibody. $\times 225$.
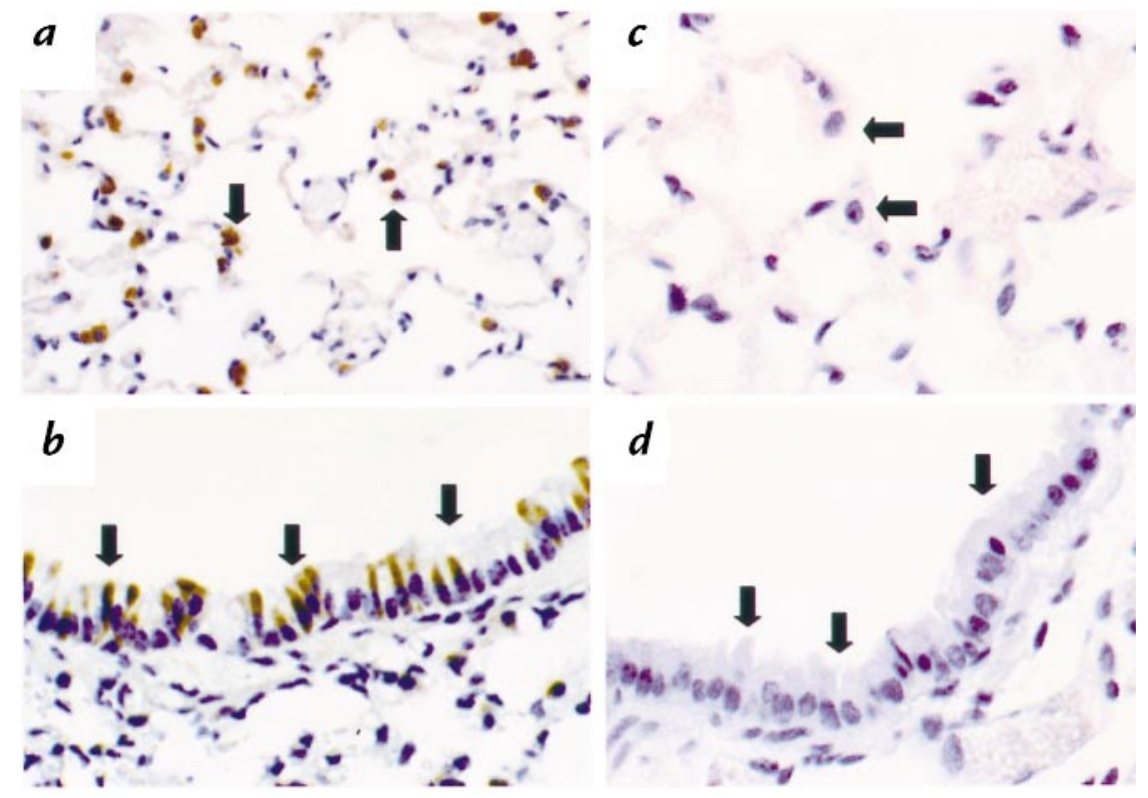

d
Samples were then kept on ice until HPLC injection, when they were protein-precipitated and neutralized by adding $300 \mu \mathrm{l}$ of a 1 $\mathrm{M} \mathrm{NaOH} /$ methanol (1:11) solution. Then $50 \mu \mathrm{l}$ of the supernatant liquid was injected into a Supelcosil LC-18 column $(15-\mathrm{cm}$ long, 4.0-mm internal diameter, $5 \mu \mathrm{m}$ ) using an HPLC system (model 1100; Hewlett-Packard, Palo Alto, California, USA). The mobile phase was $40 \%$ methanol $/ 60 \% 50 \mathrm{mM}$ potassium phosphate buffer ( $\mathrm{pH}$ 6.8). The flow rate was $1 \mathrm{ml} / \mathrm{min}$. Detection was accomplished by a fluorescence detector (model 1046A; HewlettPackard) set at $\lambda \varepsilon x=525 \mathrm{~nm}$ and $\lambda \varepsilon \mathrm{m}=550 \mathrm{~nm}$. Retention time of the MDA derivative was $2.8 \mathrm{~min}$. The assay is linear from $30 \mathrm{nM}$ to $326 \mathrm{nM}$ MDA (sensitivity is $0.5 \mathrm{pmol}$ per injection).

Glutathione. Total and oxidized glutathione was measured according to the procedure described by Liu and Kehrer (26). BALF or lung homogenate $(100 \mu \mathrm{l})$ were treated with $50 \mu \mathrm{l}$ of $0.1 \mathrm{M}$ Tris-HCl ( $\mathrm{pH} 8.5$ ) and $100 \mu \mathrm{l}$ of $25 \mathrm{mM} \mathrm{DTT}$. After keeping the samples on ice for $30 \mathrm{~min}$, the protein component was precipitated by adding $250 \mu \mathrm{l}$ of $3.75 \% 5$-sulfosalicylic acid followed by centrifugation at $3,500 \mathrm{~g}$ for $2 \mathrm{~min}$. A $200-\mu \mathrm{l}$ aliquot of the supernatant liquid was then treated with $200 \mu \mathrm{l}$ of $o$ phthaldialdehyde solution (50 mg o-phthaldialdehyde were dissolved in $0.5 \mathrm{ml}$ methanol, and the final volume was made up to $10 \mathrm{ml}$ with $0.4 \mathrm{M}$ potassium borate [ $\mathrm{pH} 9.9]$ ) for $2 \mathrm{~min}$ at room temperature. Then $200 \mu \mathrm{l}$ of $250 \mathrm{mM}$ sodium phosphate ( $\mathrm{pH}$ 7.0) was added, and $100 \mu \mathrm{l}$ of sample was injected into HPLC. For GSSG, the same procedure was applied, except for the following modifications: BAL samples were first treated with $200 \mathrm{mM} \mathrm{N}$-ethylmaleimide ( $20 \mathrm{mM}$ final concentration) to block free GSH. Lung tissue was homogenized in 5\% 5-sulfosalicylic acid containing $20 \mathrm{mM}$ NEM and $0.5 \mathrm{mM}$ EDTA.

After derivitization, the samples were injected onto a Supelcosil LC-18 column ( $15-\mathrm{cm}$ long, $4.0-\mathrm{mm}$ internal diameter, $5 \mu \mathrm{m}$ ) and eluted using a mobile phase containing $7.5 \%$ methanol $/ 92.5 \% 0.15$ $\mathrm{M}$ sodium acetate buffer ( $\mathrm{pH} 7.0)$. Fluorescence detection was performed using $\lambda \varepsilon x=340 \mathrm{~nm}$ and $\lambda \varepsilon \mathrm{m}=420 \mathrm{~nm}$. The peak retention time was $3.8 \mathrm{~min}$. The assay is linear from $25 \mathrm{nM}$ to $1 \mu \mathrm{M}$ GSH (sensitivity is $0.1 \mathrm{pmol}$ per injection).

Histopathology. The lungs from six mice in each group and at each time point were fixed in situ for microscopy by intratracheal instillation of $4 \%$ paraformaldehyde in PBS at $20 \mathrm{~cm} \mathrm{H}_{2} \mathrm{O}$ pressure for $10 \mathrm{~min}$ and subsequently removed from the thorax and immersed in additional fixative for $2 \mathrm{~h}$. These tissues were stored in $2 \%$ paraformaldehyde solution at $4^{\circ} \mathrm{C}$ until they were paraffinembedded, sectioned, and stained with hematoxylin and eosin.
Histopathologic evidence for lung injury was scored on a scale from 0 (normal) to 4 (most severe) essentially as described by Arkovitz et al. (27). Parameters assessed were the degree of vascular congestion, hemorrhagic edema, thickening of alveolar septum (edema), hyaline membrane formation in the distal airway, and neutrophil accumulation.

Cytokine measurements. Measurement of murine macrophage inflammatory protein-2 (MIP-2) in the BALF was performed by ELISA (sensitivity: $2.0 \mathrm{pg} / \mathrm{ml}$; R\&D Systems Inc., Minneapolis, Minnesota, USA) following the manufacturer's instructions. Murine tumor necrosis factor- $\alpha$ (TNF- $\alpha$ ) solid-phase sandwich ELISA (sensitivity: $3.0 \mathrm{pg} / \mathrm{ml}$; BioSource International, Camarillo, California, USA) was used to measure TNF- $\alpha$ in mice BALF following the manufacturer's instructions.

Intercellular adhesion molecule-1 (ICAM-1) mRNA levels were determined as follows. Total cytoplasmic RNA was extracted from mice lung using the Trizol Total RNA isolation kit (GIBCO BRL, Gaithersburg, Maryland, USA). RNA concentration was determined spectrophotometrically at $260 \mathrm{~nm}$. Total RNA $(1 \mu \mathrm{g})$ from each sample was reverse-transcribed into scDNA, using oligo (dT) as a primer. PCR amplification was carried out in a thermal cycler for 25 cycles for glyceraldehyde phosphate dehydrogenase (GAPDH) and 27 cycles for mouse ICAM-1 (the number of cycles were determined by titration as the acceptable cycles that can amplify visible products on ethidium bromide-stained gels during the exponential phase of the PCR). The cycling parameters routinely used were: denaturation at $94^{\circ} \mathrm{C}$ for $30 \mathrm{~s}$, annealing at $56^{\circ} \mathrm{C}$ for GAPDH or $59^{\circ} \mathrm{C}$ for ICAM- 1 for $45 \mathrm{~s}$, and extension at $72^{\circ} \mathrm{C}$ for $45 \mathrm{~s}$. Primers specific for mouse GAPDH (GAPDHF, 5'-AACTTTGGCATTGTGGAAGG-3'; GAPDHR, 5'ACACATTGGGGGTAGGAACA-3') and ICAM-1 (mICAM-1F, 5'-CGATCTTCCAGCTACCATCC-3'; mICAM-1R, 5'-GTTAAGGTCCTCTGCGTCTC-3') were used to amplify a 223-bp and 282bp fragment of mouse GAPDH and ICAM-1, respectively. The amplified products $(10 \mu \mathrm{l})$ were electrophoresed in $1.5 \%$ agarose gels, stained with ethidium bromide, and viewed under ultraviolet light. Quantification of the amplification product was obtained by densitometric scanning of the ethidium bromide-stained gels using ImageQuant (Version 1.1; Molecular Dynamics, Cambridge, Massachusetts, USA). The GAPDH signals were used to control for variation in the efficiency of RNA extraction, RT, and PCR. Levels of ICAM-1 mRNA (after normalization to GAPDH expression) were compared in the Tg vs. Wt mice at 48 , 72 , and 84 hours of hyperoxia exposure. 
Statistical analysis. Data are expressed as the mean \pm SEM. Statistical analysis was performed on an IBM-compatible personal computer with commercially available software (SigmaStat 2.03; Jandel Scientific Software, San Rafael, California, USA). Unless otherwise indicated, a one- or two-way ANOVA followed by Fisher's least significant difference test for multiple comparisons was used. A difference was considered statistically significant at $P<0.05$.

\section{Results}

Characterization of the hEC-SOD Tg mice. The strategy used for creating $\mathrm{Tg}$ mice overexpressing hEC-SOD in the mouse lung is shown in Figure 1. We initially identified five founder strains by PCR analysis of tail DNA, and all subsequent work was performed using founder strain 32 , whereas line 15 was used to rule out the possibility of a gene-insertion effect. Additionally, the hEC-SOD Tg mice appeared healthy throughout this study and showed no signs of accelerated senescence when compared with their Wt littermates.

The hEC-SOD transgene protein was only detected in the lungs of PCR-positive Tg mice and not in liver, heart, kidney, brain, skeletal muscle, small intestine, and blood, indicating a highly tissue-specific pattern of transgene expression (data not shown). The EC-SOD activity in the BALF and lung tissue of Tg mice was significantly higher than that of their Wt littermates (Table 1). In BALF, there was an approximate 2.9 -fold increase, whereas in the lung tissue, there was a threefold increase in EC-SOD enzyme activity (Table 1). The increased expression of the human transgene did not measurably affect the basal expression of endogenous mouse lung EC-SOD (Figure 2). Additionally, no effect was observed in the expression of other BALF and/or lung tissue antioxidants - namely, Mn-SOD, CuZn-SOD, GPx, catalase, and GSH (Table 1).

Immunohistochemical staining of mouse lung tissues using anti-hEC-SOD antibodies showed expression of the transgene only in type II alveolar epithelial cells (Figure $3 a$ ) and in nonciliated bronchial epithelial lining cells (Figure $3 b$ ). No staining was observed in the sections that were stained with the preimmune serum or the preabsorbed WT474 antibodies (data not shown).

Hyperoxia exposure and mortality. Exposure to $>99 \%$ oxygen was lethal to mice, especially after 84 hours. Hyperoxia was lethal to $40 \%$ of the exposed Wt mice $(12 / 30)$ and $11.6 \%$ of the Tg mice (5/43). Using the rate and proportion $z$-test, the mortality rate was significantly higher in the Wt mice $(P=0.011)$.

$B A L$ cell counts. There was no difference in total cell counts between Wt and Tg mice after 48 hours of hyperoxia (Figure 4a). However, the total cell count increased significantly by 72 hours in the Wt mice when compared with the Tg mice $\left(4.5 \times 10^{5} \pm 0.42\right.$ vs. $2.5 \times 10^{5} \pm 0.29 ; P<$ $0.05)$ and remained elevated even at 84 hours $\left(5.6 \times 10^{5} \pm\right.$ 0.54 vs. $\left.3.6 \times 10^{5} \pm 0.38 ; P<0.05\right)$. This increase in the total BAL cell count was mainly due to the disproportionate recruitment and influx of the polymorphonuclear cells (PMNs) (Figure 4b). The Wt mice showed an approximate 4.8 -fold increase in PMNs at 72 hours and a 4.7-fold increase at 84 hours over that of Tg littermates $(P$ $<0.05$; Figure $4 b)$. ND significantly $(P<0.05)$ suppressed neutrophil migration into the alveolar spaces in hyper- $a$

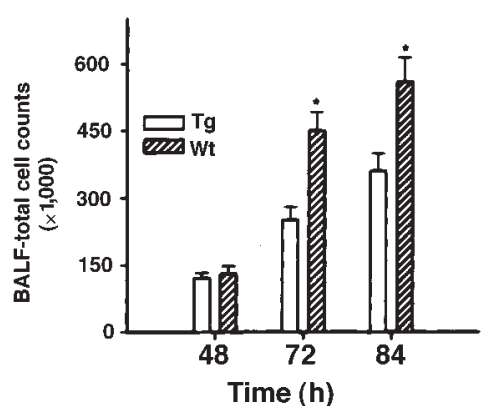

$b$

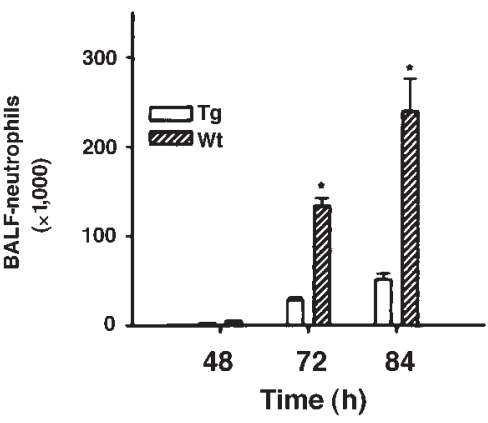

$\boldsymbol{c}$

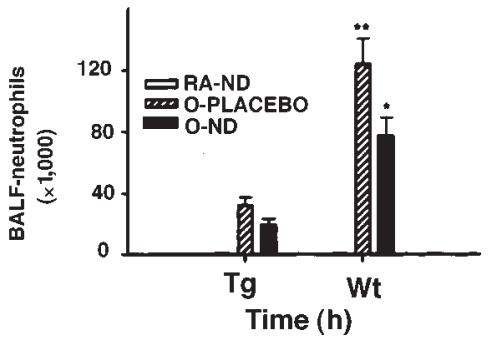

Figure 4

Total cell and PMN counts in the BALF from wild-type $(W t)$ and transgenic $(\mathrm{Tg})$ mice exposed to hyperoxia. (a) Total cell counts at 48,72 , and $84 \mathrm{~h}$ of exposure to $>99 \%$ oxygen. (b) PMN cell counts at 48,72 , and $84 \mathrm{~h}$ of exposure to $>99 \%$ oxygen. Both total cell and PMN counts significantly increased with time of exposure. (c) Tg and Wt animals were neutrophil-depleted (ND) or not (placebo), and were subsequently exposed to $>99 \%$ oxygen or room air $(R A)$ for $72 \mathrm{~h}$ followed by BALF analysis of total PMN cell counts. The Wt oxygen-exposed groups showed significant increases in PMN cell counts when compared with the Tg oxygen-exposed groups. In addition, in Wt animals, neutrophil depletion alone significantly reduced the BALF PMN cell counts vs. the oxygen-placebo (O-placebo) group. Values are expressed as mean $\pm \operatorname{SEM}(n=6) .{ }^{*} P<0.05$ between groups; ${ }^{*} P<0.01$ between groups. $B A L F$, bronchoalveolar lavage fluid; $P M N$, polymorphonuclear neutrophil.

\section{Table 1}

Antioxidant content of BALF and lung tissue from wild-type and hECSOD transgenic mice under normal conditions while breathing room air

\begin{tabular}{lcccc} 
& \multicolumn{2}{c}{$\begin{array}{c}\text { BALF } \\
\text { (per ml) }\end{array}$} & \multicolumn{2}{c}{$\begin{array}{c}\text { Lung tissue } \\
\text { (per mg total protein) }\end{array}$} \\
& Wt & $\mathrm{Tg}$ & $\mathrm{Wt}$ & $\mathrm{Tg}$ \\
CuZn-SOD (U) & $\mathrm{ND}$ & $\mathrm{ND}$ & $18.5 \pm 3.1$ & $17.3 \pm 2.4$ \\
Mn-SOD (U) & $\mathrm{ND}$ & $\mathrm{ND}$ & $0.282 \pm 0.055$ & $0.333 \pm 0.064$ \\
EC-SOD (U) & $2.23 \pm 0.11$ & $6.38 \pm 0.18^{\mathrm{A}}$ & $2.72 \pm 0.59$ & $8.19 \pm 1.05^{\mathrm{A}}$ \\
GPx (mU) & $57.0 \pm 18.3$ & $66.3 \pm 32.6$ & $212.0 \pm 80.6$ & $193.0 \pm 46.6$ \\
GSH $(\mathrm{nmol})$ & $20.3 \pm 15.6$ & $48.9 \pm 24.0$ & $6,580 \pm 690$ & $5,640 \pm 920$ \\
Catalase $(U)$ & $\mathrm{ND}$ & $\mathrm{ND}$ & $69.2 \pm 11.6$ & $75.8 \pm 14.6$
\end{tabular}

AP < 0.05. BALF, bronchoalveolar lavage fluid; CuZn SOD, copper/zinc SOD; GPX, glutathione peroxidase; $G S H$, reduced glutathione; $h E C-S O D$, human extracellular SOD; $M n-S O D$, manganese SOD; $N D$, not determined; $S O D$, superoxide dismutase; $T g$, transgenic; $W t$, wild-type. 


\section{Figure 5}

Markers of lung injury. (a) Total protein in the BALF from mice exposed to hyperoxia at 48, 72, and $84 \mathrm{~h}$. The total protein concentration increased significantly in the wild-type $(W t)$ group at $72 \mathrm{~h}$. (b) LDH activity in the BALF from mice exposed to hyperoxia at 48, 72, and $84 \mathrm{~h}$. LDH increased with time and was significantly higher in Wt mice. (c) The total protein concentration in the BALF of neutrophil-depleted (ND) animals was significantly reduced compared with non-ND oxygenexposed mice. For a given oxygen exposure group, overexpressing hEC-SOD further reduced the BALF total protein. $(\boldsymbol{d}) \mathrm{LDH}$ activity was decreased significantly in the ND mice. Values are expressed as mean \pm SEM. $(n=$ $6) .{ }^{*} P<0.05$ Wt vs. Tg group; ${ }^{*} P<0.01 \mathrm{Wt}$ vs. Tg group. $L D H$, lactate dehydrogenase. a

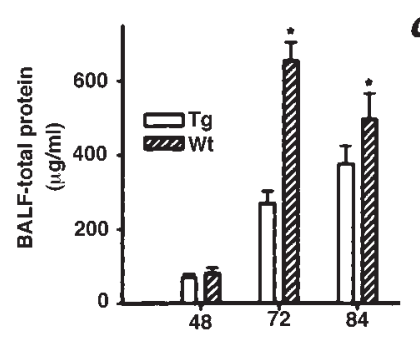

c

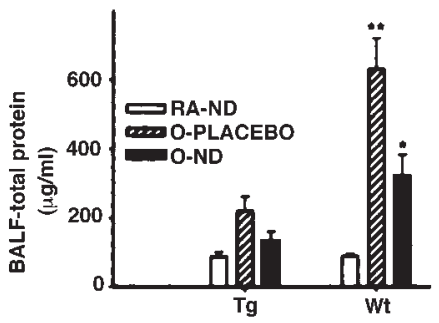

$\boldsymbol{b}$

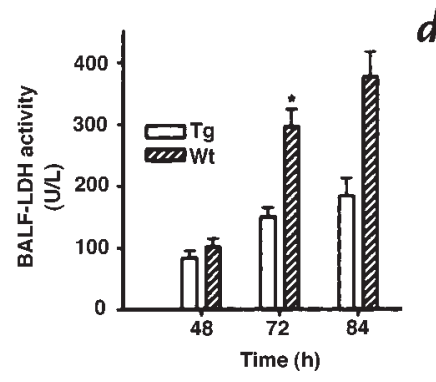

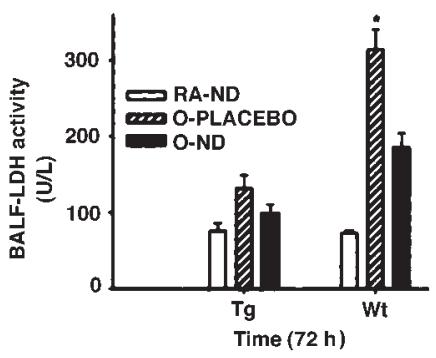

oxic mice, and overexpression of hEC-SOD further suppressed PMN BALF counts (Figure 4c).

Markers of lung injury and edema. The amount of acute lung damage elicited by hyperoxia was measured by an increase in BALF total protein and BALF LDH. Hyperoxia exposure resulted in significant increases with time of exposure for both parameters tested (Figure 5, $a$ and b). However, the EC-SOD Tg mouse strain showed a marked attenuation of these lung injury parameters, at both 72 and 84 hours, when compared with their Wt littermates $(P<0.05)$. ND in Wt mice significantly lessened hyperoxic damage to the lung by 72 hours of exposure as assessed by the total protein and LDH in the BALF (Figure 5, $c$ and d). ND in the Tg mice showed a trend to decrease further acute lung damage, but this difference was not found to be significant (Figure 5, $c$ and $d$ ).

We used the lung wet/dry ratio in an attempt to probe pulmonary capillary permeability differences between the two groups of mice. The length of hyperoxia exposure correlated with an increase in pulmonary edema fluid as measured by the wet/dry ratio (Figure $6 a$ ). The edema was significantly higher in the Wt mice at 84 hours when compared with EC-SOD Tg littermates $(P<0.05)$. Furthermore, ND decreased the lung permeability significantly $(P<0.05)$ in the $\mathrm{Wt}$ mice. However, no significant difference was noted between the ND and non-ND Tg mice (Figure 6b).

Specificity of EC-SOD expression in Tg mice strains. Studies were undertaken to determine whether the tolerance of $\mathrm{Tg}$ animals to hyperoxia was the direct result of overexpressing hEC-SOD in the mouse lung or simply due to the transgene's random insertion into the mouse genome. A second mouse $\mathrm{Tg}$ founder line, line 15 , was partly characterized and shown to have similar levels of hEC-SOD in the mouse lung as was found in line 32. Six animals each from line 15, line 32, and Wt were exposed to $>99 \% \mathrm{O}_{2}$ for 72 hours, and the development of acute lung injury was determined as measured by the total protein and LDH in the BALF. We found Tg line 15 and line 32 to have similar levels of protection from hyperoxia, as judged by BALF protein, and both were significantly less than Wt (288 \pm
$182,220 \pm 101,633 \pm 218 \mu \mathrm{g} / \mathrm{ml}$, respectively; $P<0.05)$. Parallel findings were also noted for LDH levels in BALF $(153 \pm 35,132 \pm 42,314 \pm 63 \mathrm{U} / 1$, respectively; $P<0.05)$. We interpret these findings to mean that the tolerance to hyperoxia in the hEC-SOD Tg mice is the result of overexpression of the transgene and is not due to local gene effects of inserting DNA into the mouse genome.

Lung antioxidants. At each of the time points indicated, the total SOD activity was significantly higher in BALF and lung homogenate in Tg vs. Wt mice (Figure 7, $a$ and $b$ ) and was mainly due to increases in the hEC-SOD isoenzyme (data not shown). Although the total SOD activity showed a trend to increasing with time of hyperoxia exposure in the $\mathrm{Wt}$ animals, this was not significant (Figure 7, $a$ and $b$ ).

The total glutathione content in the lung tissue (Wt: $9.7 \pm 1.5,14.7 \pm 1.3,17.5 \pm 1.4 \mu \mathrm{mol} / \mathrm{mg}$ protein; Tg: 10.4 $\pm 2.0,14.5 \pm 1.0$, and $18.0 \pm 1.0 \mu \mathrm{mol} / \mathrm{mg}$ protein at 48,72 , and 84 hours, respectively) and the BALF (Wt: $4.8 \pm 1.1$, $6.3 \pm 1.0,8.6 \pm 0.8 \mathrm{nmol} / \mathrm{ml} ; \mathrm{Tg}: 4.6 \pm 1.0,4.9 \pm 0.6$, and 7.0 $\pm 0.9 \mathrm{nmol} / \mathrm{ml}$ at 48,72 , and 84 hours, respectively) increased significantly with time of hyperoxia exposure but did not differ between the two groups of mice.

The level of catalase activity was significantly increased $(P<0.05)$ in the hyperoxia-exposed Tg mice, most prominently during the 72 -hour adaptation period, and began to decrease by 84 hours in the two groups of mice (Figure 8a). The GPx activity in BALF increased significantly $(P<0.05)$ with time of exposure in both groups of animals but showed significantly higher levels $(P<0.05)$ in Tg mice at 84 hours compared with Wt littermates (Figure 8b). There was no discernible pattern of GPx activity in the total lung preparations in the two groups of mice (Figure $8 c$ ).

Oxidation of glutathione and lipids. The percentage of the GSSG was significantly increased in the lung tissues of Wt and Tg mice by 84 hours of exposure (Wt: $19.6 \pm 2.4$, $53.0 \pm 4.5,71.0 \pm 6.1 ; \mathrm{Tg}: 21.0 \pm 2.1,66 \pm 8.4,86.0 \pm 9.5$ at 48,72 , and 84 hours, respectively). In the BALF, the percentage of oxidized GSSG also increased signifi- 
cantly with time of exposure (Wt: 66.2 $\pm 4.7,75.2 \pm 7.7$, $82.1 \pm 7.0$; Tg: $45.3 \pm 7.0,69.6 \pm 13.5,85.5 \pm 5.8$ at 48,72 , and 84 hours, respectively). At 72 hours of hyperoxia, ND independently and significantly reduced the GSSG levels in BALF (Figure 9a).

Exposure to hyperoxia resulted in enhanced lipid peroxidation, as measured by levels of MDA in both the BALF and lung tissue and increased with the time of exposure. In the Wt BALF, MDA levels measured $43.5 \pm$ $4.1,305.6 \pm 41.5$, and $417.2 \pm 49.8 \mathrm{pmol} / \mathrm{ml}$ at 48,72 , and 84 hours of exposure, respectively, whereas BALF, MDA levels in Tg mice measured $19 \pm 1.3,123.7 \pm 14$, and 396.6 $\pm 33.7 \mathrm{pmol} / \mathrm{ml}$. The difference between $\mathrm{Wt}$ and Tg animals was significant $(P<0.05)$ at 72 hours of exposure. When total lung MDA levels were measured, they showed an increase with time of exposure in the two groups but no significant differences between them (Wt: $9.4 \pm 1.4,16.7 \pm 2.5,21.2 \pm 2.4 \mathrm{pmol} / \mathrm{mg}$ protein at 48,72 , and 84 hours; Tg: $8.8 \pm 10,20.5 \pm 1.9,24.7 \pm 1.6 \mathrm{pmol} / \mathrm{mg}$ protein at 48,72 , and 84 hours, respectively). After 72 hours of hyperoxia exposure, there was a significant attenuation of BALF lipid peroxidation in ND Wt mice when compared with non-ND animals (Figure 9b). A further attenuation of BALF MDA levels was seen in ND Tg mice (Figure 9b).

Effect of byperoxia on cytokine release in the BALF. The levels of TNF- $\alpha$ and MIP-2 in the BALF from ND and nonND Wt and Tg mice were measured after exposure to either 72 hours of $>99 \% \mathrm{O}_{2}$ or to room air. With room air exposure, the levels of TNF- $\alpha$ and MIP- 2 in the BALF of Wt and $\mathrm{Tg}$ mice did not differ from each other and were near the limits of detection of our assays (Figure $10, a$ and $b$ ). The two cytokines levels were significantly increased in the hyperoxia-exposed Wt animals, whereas these responses were blunted in the ND mice and even further so in the $\mathrm{Tg}$ animals.

ICAM-1 expression. To characterize further the mechanisms that underlie low neutrophil influx in the $\mathrm{Tg}$ mice lungs in response to hyperoxia, ICAM-1 mRNA levels were determined by RT-PCR analysis. The amount of GAPDH mRNA transcripts was used as a control for the RT-PCR reactions. The level of ICAM-1 mRNA was significantly different between the two groups after hyperoxia exposure (Figure 11). Hyperoxia induced a twofold increase in ICAM-1 mRNA in the lungs of Wt mice within 84 hours of exposure compared with $\mathrm{Tg}$ animals. The level of ICAM-1 mRNA was not significantly different in the two groups of animals at 48 hours of exposure, whereas 72 hours of hyperoxia elicits an increase in ICAM-1 mRNA in the lungs of both groups of animals.

Histopathology. At each time point (48, 72, and 84 hours), the lungs of both Wt and $\mathrm{Tg}$ mice were fixed, sectioned, stained, and examined for evidence of lung injury. Using a previously described scoring scheme (27), pathological changes were recorded based on the degree of pulmonary edema, hyaline membrane formation, alveolar septal thickening, and inflammatory cell infiltration. Evidence of vascular injury was detected in the Wt mice as early as after 48 hours of hyperoxic exposure (data not shown). After 72 hours of hyperoxia exposure, the majority of lungs examined from Wt mice showed evidence for decreased pulmonary compliance as indi- $a$

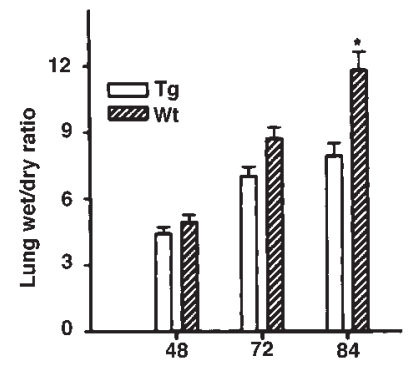

$\boldsymbol{b}$

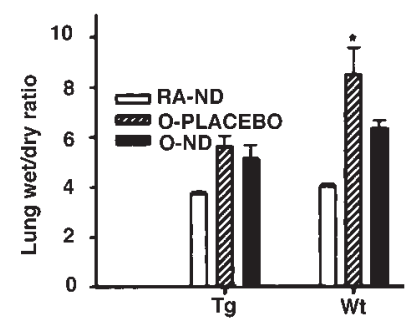

Figure 6

Lung edema. (a) Lung wet/dry ratios at 48,72 , and $84 \mathrm{~h}$ of exposure to hyperoxia. A significant increase in the wet weight of wild-type $(W t)$ lungs was observed at $84 \mathrm{~h}$ of hyperoxic exposure. (b) After $72 \mathrm{~h}$ of hyperoxia exposure, neutrophil depletion and overexpression of hEC-SOD decreased lung wet/dry ratio significantly in the Wt vs. transgenic $(\mathrm{Tg})$ group $\left({ }^{*} P<0.05\right)$. Values are expressed as mean $\pm \operatorname{SEM}(n=6)$.
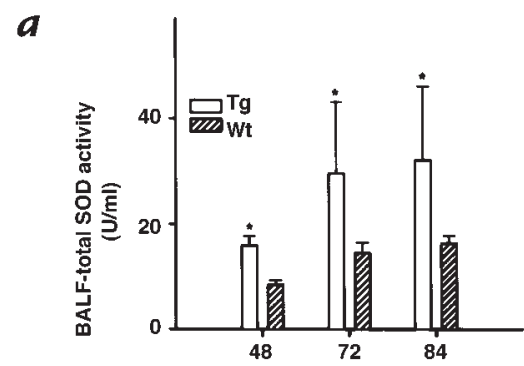

$\boldsymbol{b}$

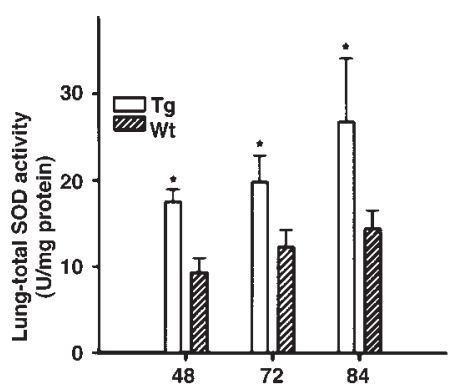

Figure 7

Total SOD in the lung and BALF from mice exposed to hyperoxia. (a) SOD activity $(\mathrm{U} / \mathrm{ml} \mathrm{BALF})$ in the BALF of the transgenic $(T g)$, but not wild-type $(W t)$, mice increased significantly with time. There was a trend to increasing with time in $\mathrm{Wt}$, but this was not significant. (b) The total SOD activity $(\mathrm{U} / \mathrm{mg}$ lung protein) in the lung homogenate of both Wt and $\mathrm{Tg}$ mice showed a trend to increasing with time of oxygen exposure, but this was not significant. At the three time points tested, Tg mice showed significantly higher enzyme activities compared with Wt controls. Values are expressed as mean $\pm \operatorname{SEM}(n=6) .{ }^{*} P<0.05 \mathrm{Tg}$ vs. Wt. 
$a$

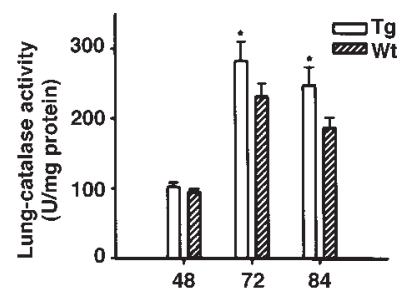

$\boldsymbol{b}$

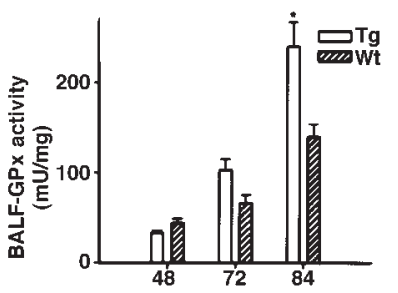

$c$

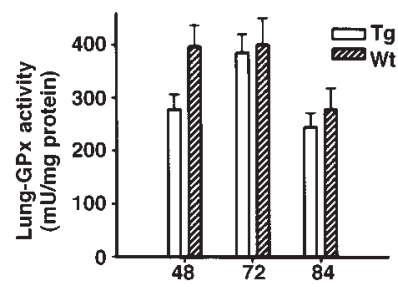

\section{Figure 8}

Antioxidant enzymes levels after hyperoxia exposure. (a) Catalase activity was measured in the total lung homogenate from mice exposed to hyperoxia. The enzyme activity increased significantly with time in transgenic $(T g)$ and wildtype $(W t)$ mice. (b) GPx activity was measured in the BALF of mice after exposure to hyperoxia. The enzyme increased significantly by $84 \mathrm{~h}$ of exposure. (c) GPx activity in the total lung homogenate from mice after exposure to hyperoxia. Values are expressed as mean $\pm \operatorname{SEM}(n=6) .{ }^{*} P<0.05 \mathrm{Tg}$ vs. Wt. GPx, glutathione peroxidase.

\section{$a$}

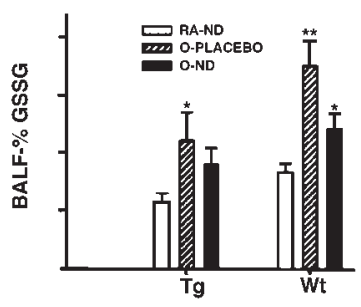

$\boldsymbol{b}$

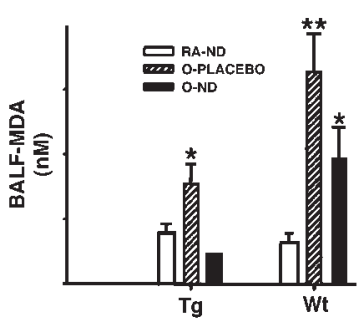

Figure 9

Markers of oxidative stress in the BALF after $72 \mathrm{~h}$ of hyperoxia exposure. (a) The level of oxidized GSH was significantly elevated in all groups after $72 \mathrm{~h}$ of $>99 \%$ oxygen exposure, particularly in the oxygen-placebo (O-placebo) wildtype $(W t)$ mice in which the level of oxidized glutathione (CSSG) exceeds the GSSG levels in the other groups of mice. (b) The level of lipid peroxides measured as malondialdehyde was significantly attenuated in the neutropenic animals and hEC-SOD transgenic $(T g)$ mice. Values are expressed as mean \pm SEM $(n=6) .{ }^{*} P<0.05$ Tg vs. Wt, and neutrophil-depleted (ND) vs. controls; ${ }^{*} P<0.01 \mathrm{Tg}$ vs. Wt, and ND vs. controls. GSH, reduced glutathione. cated by increased edema, thickening of the alveolar septal walls, hyaline membrane formation, vascular and interstitial congestion, hemorrhage, and diffuse inflammatory cell infiltration (Figure 12a), whereas mild histopathologic changes were seen in the Tg mice (Figure $12 b$ ). Increased microscopic lung damage was also observed in Tg mice after 84 hours of hyperoxia exposure; however, it was less severe than the injury seen in the Wt animals (data not shown).

\section{Discussion}

Persistent exposure to hyperoxia results in a series of events that eventually lead to irreversible pulmonary toxicity and death in most species examined, including humans (2). The early stages of pulmonary toxicity begins with an initiation phase in which no morphologic evidence of lung injury can be seen. This is followed by an inflammatory phase in which subtle pathological changes are present. This phase is also associated with an influx of predominantly polymorphonuclear inflammatory cells, which when activated, may further enhance the oxidative stress by releasing large quantities of extracellular free radical species from membrane-bound oxidases. These ROS may further amplify the hyperoxic lung injury. Ultimately, alveolar and capillary destruction and respiratory failure will ensue if the source of the oxidative stress is not removed or attenuated.

The goal of these studies was to examine the contribution extracellular oxidants play in the development of hyperoxic-induced lung toxicity. To begin to address this question, we engineered $\mathrm{Tg}$ mice in which alveolar and airway epithelial cells were specifically targeted to overexpress human extracellular superoxide dismutase. Because EC-SOD is a secreted protein, we found significant quantities of this extracellular antioxidant in the distal airway epithelial lining fluids. Thus, we were able to enhance markedly the antioxidant capacity of the epithelial lining fluid, an extracellular pulmonary compartment in which antioxidant reserves may play critical roles in preserving pulmonary function (28).

The increased expression of EC-SOD did not influence the expression of other pulmonary antioxidants under basal physiological conditions. However, adaptation of the Tg mice to hyperoxia exposure was associated with increases in lung catalase activity and BAL GPx activity, as well as increases in the level of GSH. Previous investigators have documented that $\mathrm{O}_{2}{ }^{-}$can inactivate catalase and peroxidase $(29,30)$. Our findings suggest that ECSOD may be able to minimize the negative effects of $\mathrm{O}_{2}{ }^{-}$ on cellular catalase and extracellular GPx, perhaps by decreasing its half-life. Considerably smaller increases in the BAL GPx and GSH occurred during the adaptation of Wt mice to hyperoxia exposure. This suggests that extracellular antioxidant enzymes may further enhance the hyperoxic-induced pulmonary antioxidant response. On the other hand, intracellular GPx-1 may have a limited role in the defense against oxygen toxicity, given that mice lacking intracellular GPx-1 showed no increased sensitivity to hyperoxia (31). Also, recent studies have shown that GSH content of the lung was not an important determinant of hyperoxia lethality (32). Hyperoxia has been reported to increase the enzyme activity levels 


\section{Figure 10}

Inflammatory cytokine levels in BALF after $72 \mathrm{~h}$ of hyperoxia exposure. (a) The level of TNF- $\alpha$ measured in the BALF after $72 \mathrm{~h}$ of $>99 \%$ oxygen exposure increased significantly in all hyperoxic $(O)$ groups. In the oxygen-exposed groups, both neutrophil depletion and overexpressing hEC-SOD resulted in significantly lower TNF- $\alpha$. The levels of TNF- $\alpha$ in the room air-exposed mice were below the limits of detection. $(\boldsymbol{b})$ The levels of MIP-2 were measured in BALF after 72 h of $>99 \%$ oxygen exposure and demonstrated a pattern similar to TNF- $\alpha$. The levels of MIP-2 in the BALF of room air-exposed mice were very low and typically below the limits of detection. Values are expressed as mean $\pm \operatorname{SEM}(n=6) .{ }^{*} P<0.05$ transgenic $(T g)$ vs. wild-type $(W t)$, and neutrophil-depleted $(N D)$ vs. controls; ${ }^{*} P<0.01 \mathrm{Tg}$ vs. Wt, and ND vs. controls. MIP-2, macrophage inflammatory protein-2; TNF- $\alpha$, tumor necrosis factor- $\alpha$. a

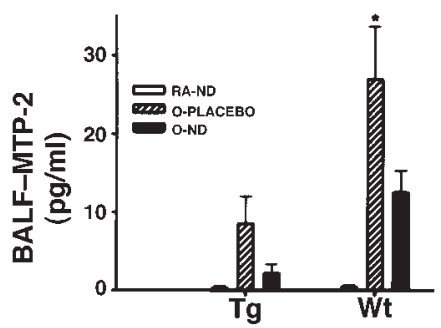

b

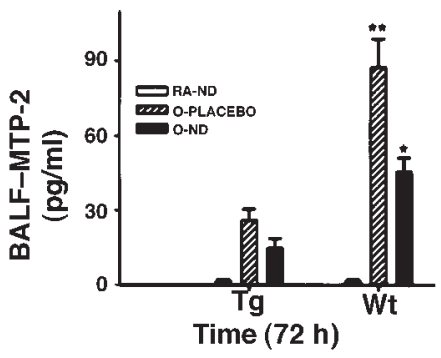

of catalase and GPx and to decrease Mn-SOD activity, but it does not alter CuZn-SOD enzyme activity (33).

The mechanisms of tolerance to pulmonary oxygen toxicity by elevated levels of Tg SODs are not entirely clear. Certainly, many experimental data have shown that excessive quantities of toxic oxygen metabolites, including superoxide and hydrogen peroxide, are evolved at multiple cellular sites during exposure to hyperoxic environments (17). The antioxidant enzyme EC-SOD is a secreted protein that exists in the interstitial space of tissues and appears to be bound mostly to heparan sulfate proteoglycans via a positively charged $\mathrm{COOH}$-terminal heparin-binding domain (34). Heparan sulfate proteoglycans exist in the glycocalyx of cell surfaces and in the connective tissue matrix. This location may position EC-SOD to intercept $\mathrm{O}_{2}^{-}$released by phagocytic leukocytes and other cell types. Increased EC-SOD levels could decrease toxicity by decreasing availability of superoxide and, therefore, lessen the direct and indirect reactions of ROS with cellular constituents. In addition, it is quite possible that increased levels of EC-SOD act to decrease the formation of deleterious secondary metabolites of arachidonic acid and nitrites (16). These metabolites are known to function as potent chemotaxins for PMNs and macrophages. Their accumulation and activation will likely amplify the production of excessive ROS. EC-SOD, by lowering $\mathrm{O}_{2}{ }^{-}$levels, may decrease the very rapid reaction of superoxide with nitric oxide (35) and, thus, effectively increase the half-life of NO while

\section{Figure 11}

Intercellular adhesion molecule-1 (ICAM-1) mRNA levels in the lung. After exposure to 48,72 , and $84 \mathrm{~h}$ of $>99 \%$ hyperoxia, total RNA was extracted from both wild-type $(W t)$ and transgenic $(T g)$ mouse lungs and subjected to reverse transcriptase-PCR with primers specific for ICAM- 1 and glyceraldehyde phosphate dehydrogenase $(G A P D H)$ as outlined in the text. Aliquots of each PCR reaction were electrophoresed on agarose gels, stained with ethidium bromide, and signal intensity determined. Four animals were used at each time point. The top graph shows the raw agarose gel, and the bottom graph shows the level of ICAM-1 mRNA after normalization to GAPDH mRNA levels. ${ }^{*} P<0.05$. decreasing the net production of peroxynitrite, a powerful oxidant species. Additionally, endothelial cell-derived $\mathrm{NO}$ is capable of degrading heparin and heparan sulfate via $\mathrm{HNO}_{2}$, resulting in degradation of the extracellular matrix (36). Increased levels of EC-SOD at these sites may protect extracellular matrix damage and the subsequent tissue injury from inflammatory responses and possible release of growth factors and cytokines. Furthermore, EC-SOD may decrease the superoxide anion radicals that are available to react with $\mathrm{H}_{2} \mathrm{O}_{2}$, resulting in the formation of hydroxyl radicals (37). Also SODs can inhibit any free radical chain reaction in which superoxide serves as initiator and/or propagator and hence decrease the net production of $\mathrm{H}_{2} \mathrm{O}_{2}$ (38). Further supporting our model are data from Carlsson et al. (17) that show that ECSOD knockout mice develop normally but were found to be more susceptible to the toxic effects of $1 \mathrm{~atm}$ of $\mathrm{O}_{2}$.
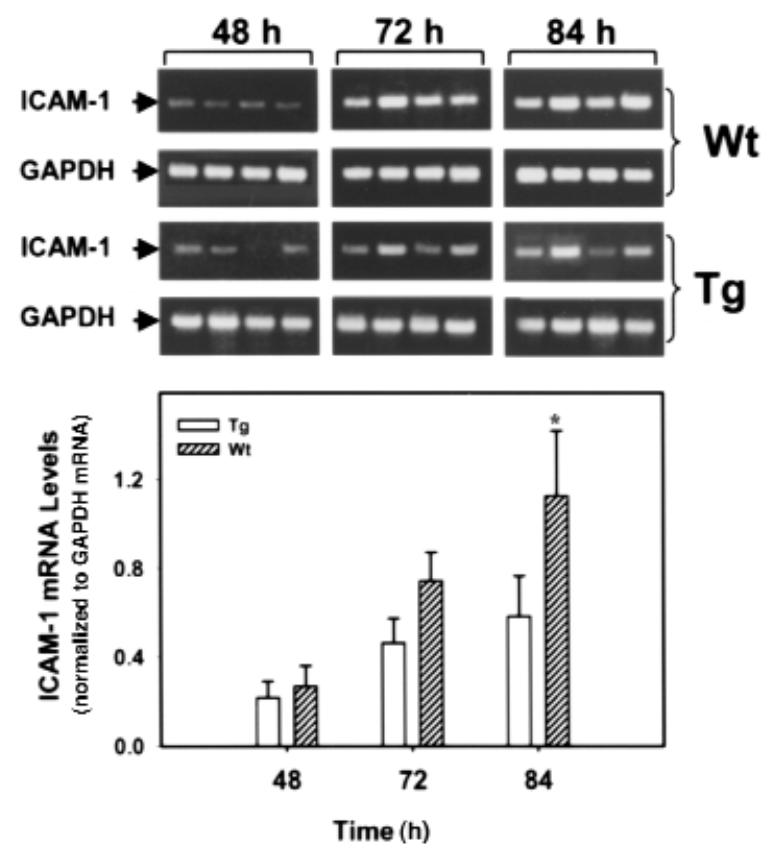


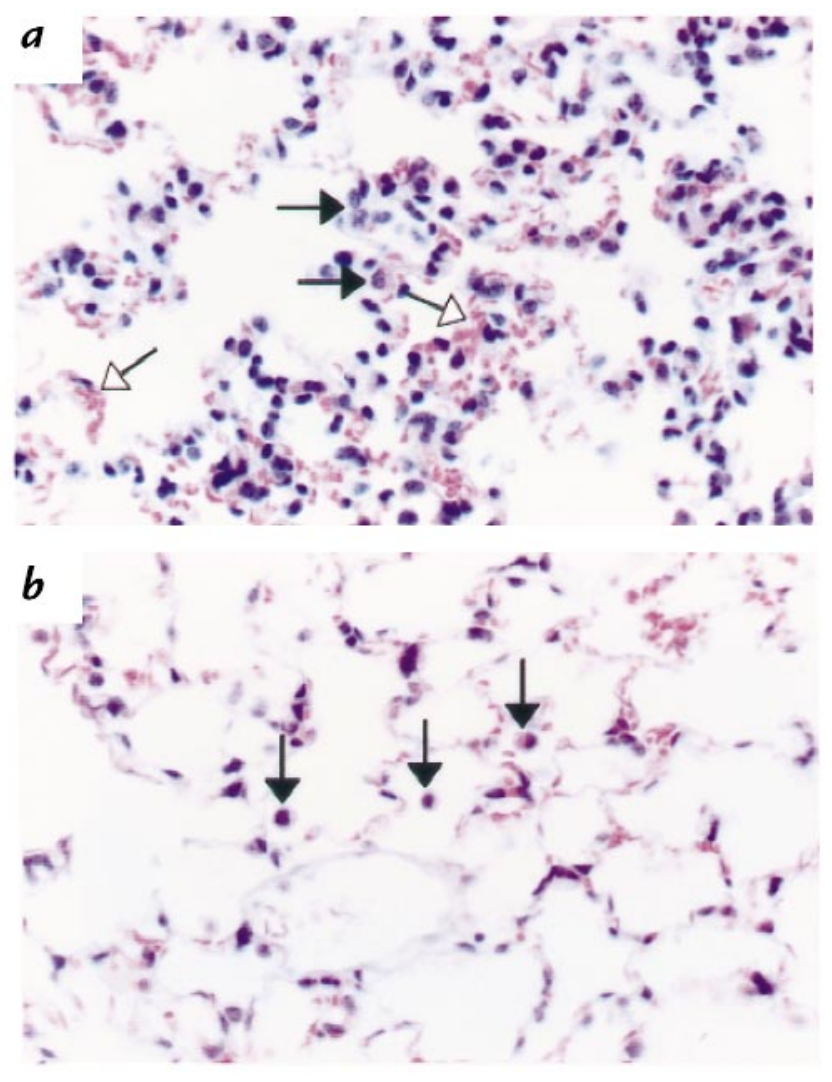

Figure 12

Light microscopy of paraffin-embedded and hematoxylin and eosin-stained section of representative lungs from mice exposed to hyperoxia. (a) Representative lung sections from Wt mice exposed to $72 \mathrm{~h}$ of >99\% oxygen showing hyaline membrane formation (open arrows), alveolar septal thickening, and cellular infiltration composed mainly of macrophages and PMNs (filled arrows). (b) Representative lung sections from $\mathrm{Tg}$ mice exposed to $72 \mathrm{~h}$ of $>99 \%$ oxygen showing modest alveolar septal thickness and fewer numbers of alveolar macrophages (filled arrows) and PMNs. Original magnification: $\times 132$.

Considerable experimental data suggest that PMN leukocytes play a vital role in amplifying oxidative stress during inflammation (39). Activated neutrophils produce superoxide free radicals by the NADPH oxidase-mediated univalent reduction of molecular oxygen. Additionally, activated neutrophils can release cytokines, proteases, elastases, myeloperoxidase, and other enzymes. These substances may upregulate adhesion molecule receptors, enhance chemotaxis, increase vascular permeability, damage tissues directly, and impair endothelial function (40). A role for PMNs in acute hyperoxic injury to the lungs has been considered but never proved in vivo. In our study, Tg mice overexpressing EC-SOD significantly reduced hyperoxia-induced infiltration of PMNs by approximately 50\% when compared with Wt littermates. The decrease in the number of PMNs would be predicted to be beneficial by reducing the levels of extracellular free radicals and lowering proteolytic enzymes released. On the other hand, it is possible that protection against hyperoxic injury, as seen in the hEC-SOD Tg mice, may be unrelated to lung neutrophil accumulation. To dissect out the contribution decreased PMNs play in preserving lung function in our $\mathrm{Tg}$ mice overexpressing hEC-SOD, we neutrophil-depleted Wt and Tg animals using anti-neutrophil antibodies and studied the effects in our hyperoxia animal model system. We demonstrate that ND in Wt mice can abrogate the inflammatory response after hyperoxia and reduce alveolar capillary protein leak. The protection afforded to the ND Wt mice provides additional evidence for the potential detrimental role neutrophils play in hyperoxic acute lung injury. Furthermore, ND of Tg mice provided additional protection over that observed in the Wt controls.

Previous studies on the effects of ND in hyperoxic lung injury have shown both protective responses (41) and no effects (41). However, these studies varied with regard to the age and sex of the animals, degree of neutropenia achieved, and agent used to deplete neutrophils. For example, Smith et al. (42) reported a reduction of absolute neutrophil counts to $93 \pm 40$ cells $/ \mathrm{mm}^{3}$ by using mechlorethamine hydrochloride; however, no protection from hyperoxia damage was achieved in his study. This may be due to known toxic alkylating and GSH-depleting side effects of mechlorethamine hydrochloride (43). Our observation suggests that the protective effects of EC-SOD is mediated, at least in part, by its ability to attenuate the influx of PMNs.

Lung lavage levels of cytokines were measured, as they have been shown to be fundamental modulators of injury and inflammation. In situ elaboration (or blocking) of various inflammatory cytokines has been found to induce (or abrogate) lung injury (44). As such, we looked at levels of a number of key inflammatory (TNF$\alpha$ ) and chemotactic (MIP-2) cytokines. At 72 hours after hyperoxia exposure, significant increases of TNF- $\alpha$ and MIP-2 levels were measured in the BALF of Wt and Tg animals, and this is in accord with the findings of others $(45,46)$. Recent studies have shown that exogenous administration of TNF- $\alpha$ can increase pulmonary oxygen tolerance. The protective effects of this cytokine have been associated with the induction of Mn-SOD, but not CuZn-SOD, in vivo $(47,48)$. In our study, hyperoxia induced significantly higher levels of TNF- $\alpha$ protein in the BALF of Wt mice vs. hEC-SOD Tg mice. Thus, our studies demonstrate that the protective effects of increased EC-SOD expression are not mediated via stimulation of TNF- $\alpha$ production. However, the possibility exists that the protective effects of hEC-SOD transgene may be mediated, at least in part, by its ability to inhibit hyperoxia-induced TNF- $\alpha$ and MIP- 2 production. The latter possibility will require further investigation, but the involvement of TNF- $\alpha$ in the pathogenesis of pulmonary oxygen toxicity remains controversial $(45,46)$.

Neutrophil migration into pulmonary tissues coincides with upregulation of ICAM-1 mRNA and protein in hyperoxia exposure of mice lungs (49). ICAM-1 mediates transendothelial migration of neutrophils (50). Additionally, ICAM-1 is a major adhesion molecule produced by inflamed vascular endothelial cells and has been used as a sensitive indicator of intravascular inflammation (51). An interesting finding in our studies was the weak levels of ICAM-1 expression after hyperoxia in hEC-SOD Tg mice lungs compared with the heavy expression observed in Wt mice lungs. This suggests that the reduction in infiltration of PMNs into pulmonary airspaces of the hEC-SOD Tg mice after exposure to hyperoxia may be 
mediated, at least in part, via regulation of ICAM-1 expression. However, these experiments do not differentiate between cause and effects. For example, overexpression of EC-SOD may inhibit neutrophil recruitment, which may decrease lung injury. Alternatively, increased expression of EC-SOD may decrease lung injury, which would in turn decrease recruitment of PMNs. It is also important to recognize that the tolerance of the hECSOD Tg mice to hyperoxia has been observed in the absence of infiltration of PMNs. For example, the levels of lipid peroxidation and GSSG in the BALF of neutropenic $\mathrm{Tg}$ mice were significantly lower than in the BALF of the neutropenic Wt mice after $>99 \% \mathrm{O}_{2}$ exposure.

Overexpression of hEC-SOD in alveolar type II and nonciliated bronchial epithelial cells confers protection against hyperoxic-induced lung injury. One significant mechanism by which this occurs is via an attenuation of the neutrophil inflammatory response. Whether EC-SOD directly or indirectly reduces the expression of ICAM-1, TNF- $\alpha$, and MIP- 2 after hyperoxia is not completely understood. In addition, extracellular markers of oxidative stress are attenuated in the Tg animals. Therefore, the mechanisms for tolerance to oxygen toxicity, as exhibited by the hEC-SOD Tg mice, are more likely multifactorial in pathogenesis. We conclude that EC-SOD, when present in the extracellular compartments of the lung and airway, is a recognizable modulator of the complex response of pulmonary tissue to hyperoxic insult.

\section{Acknowledgments}

We are indebted to Claude Piantadosi for assistance with hyperoxia exposures. The technical expertise of Jiazhen Guan and of members of the Duke University Comprehensive Cancer Center Transgenic Mouse Facility is gratefully acknowledged. We thank Alfred Hausladen for critical review of this manuscript. This work was funded in part by National Institutes of Health grants HL-55166 and ES/HL-08698, and an American Heart Association Grant-in-Aid (to R.J. Folz). R.J. Folz is a Parker B. Francis Fellow in Pulmonary Research.

1. Morris, A.H. 1994. Adult respiratory distress syndrome and new modes of mechanical ventilation: reducing the complications of high volume and high pressure. New Horiz. 2:19-33.

2. Folz, R.J., and Crapo, J.D. 1994. Pulmonary oxygen toxicity. In Current pulmonology. 15 th ed. D.F. Tierney, editor. Mosby Year-Book Inc. Chicago, IL. 113-136.

3. Gille, J.J.P., van Berkel, C.G., and Joenje, H. 1994. Mutagenicity of metabolic oxygen radicals in mammalian cell cultures. Carcinogenesis. 15:2695-2699.

4. Janssen, Y.M., Van Houten, B., Borm, P.J., and Mossman, B.T. 1993. Cell and tissue responses to oxidative damage. Lab. Invest. 69:261-274.

5. Suttorp, N., and Simon, L.M. 1982. Lung cell oxidant injury. Enhancement of polymorphonuclear leukocyte-mediated cytotoxicity in lung cells exposed to sustained in vitro hyperoxia. J. Clin. Invest. 70:342-350.

6. Clement, A., Edeas, M., Chadelat, K., and Brody, J.S. 1992. Inhibition of lung epithelial cell proliferation by hyperoxia. Posttranscriptional regulation of proliferation-related genes. J. Clin. Invest. 90:1812-1818.

7. Gardner, P.R., Nguyen, D.D.H., and White, C.W. 1994. Aconitase is a sensitive and critical target of oxygen poisoning in cultured mammalian cells and in rat lungs. Proc. Natl. Acad. Sci. USA. 91:12248-12252.

8. Schoonen, W.G., Wanamarta, A.H., van der Klei-van Moorsel, J.M. Jakobs, C., and Hoenje, H. 1990. Respiratory failure and stimulation of glycolysis in Chinese hamster ovary cells exposed to normobaric hyperoxia. J. Biol. Chem. 265:1118-1124.

9. White, C.W., Avraham, K.B., Shanley, P.F., and Groner, Y. 1991. Transgenic mice with expression of elevated levels of copper-zinc superoxide dismutase in the lungs are resistant to pulmonary oxygen toxicity. J. Clin. Invest. 87:2162-2168.

10. Wispe, J.R., et al. 1992. Human Mn-superoxide dismutase in pulmonary epithelial cells of transgenic mice confers protection from oxygen injury.
J. Biol. Chem. 267:23937-23941.

11. Marklund, S.L. 1984. Extracellular superoxide dismutase and other superoxide dismutase isoenzymes in tissues from nine mammalian species. Biochem. J. 222:649-655.

12. Marklund, S.L. 1982. Human copper-containing superoxide dismutase of high molecular weight. Proc. Natl. Acad. Sci. USA. 79:7634-7638.

13. Willems, J., et al. 1993. Purification and sequence of rat extracellular superoxide dismutase B secreted by $\mathrm{C}_{6}$ glioma. J. Biol. Chem. 268:24614-24621.

14. Folz, R.J., et al. 1997. Mouse extracellular superoxide dismutase: primary structure, tissue-specific gene expression, chromosomal localization and lung in situ hybridization. Am. J. Respir. Cell Mol. Biol. 17:393-403.

15. Oury, T.D., Crapo, J.D., Valnickova, Z., and Enghild, J.J. 1996. Human extracellular superoxide dismutase is a tetramer composed of two disulfide-linked dimers: a simplified, high yield purification of extracellular superoxide dismutase. Biochem. J. 317:51-57.

16. Freeman, B.A., and Crapo, J.D. 1981. Hyperoxia increases oxygen radical production in rat lungs and lung mitochondria. J. Biol. Chem. 256:10986-10992

17. Carlsson, L.M., Jonsson, J., Edlund, T., and Marklund, S.L. 1995. Mice lacking extracellular superoxide dismutase are more sensitive to hyperoxia. Proc. Natl. Acad. Sci. USA. 92:6264-6268.

18. Korfhagen, T.R., et al. 1990. Cis-acting sequences from a human surfactant protein gene confer pulmonary-specific gene expression in transgenic mice. Proc. Natl. Acad. Sci. USA. 87:6122-6126.

19. Folz, R.J., and Crapo, J.D. 1994. Extracellular superoxide dismutase (SOD3): tissue-specific expression, genomic characterization, and computer-assisted sequence analysis of the human EC-SOD gene. Genomics. 22:162-171

20. Marklund, S.L. 1990. Analysis of extracellular superoxide dismutase in tissue homogenates and extracellular fluids. Methods Enzymol. 186:260-265.

21. Crapo, J.D., McCord, J.M., and Fridovich, I. 1978. Preparation and assay of superoxide dismutases. Methods Enzymol. 53:382-393.

22. Aebi, H. Catalase in vitro. 1984. Methods Enzymol. 105:121-126.

23. Flohe, L., and Gunzler, W.A. 1984. Assays of glutathione peroxidase. Methods Enzymol. 105:114-121.

24. Connolly, E.S., Jr., et al. 1996. Cerebral protection in homozygous null ICAM-1 mice after middle cerebral artery occlusion. J. Clin. Invest. 97:209-216

25. Wong, S.H.Y., et al. 1987. Lipoperoxides in plasma as measured by liquidchromatographic separation of malondialdehyde-thiobarbituric acid adduct. Clin. Chem. 33:214-220.

26. Liu, H., and Kehrer, J.P. 1996. The reduction of glutathione disulfide produced by t-butyl hydroperoxide in respiring mitochondria. Free Radic. Biol. Med. 20:433-442.

27. Arkovitz, M.S., et al. 1997. Decreased pulmonary compliance is an early indicator of pulmonary oxygen injury. J. Surg. Res. 67:193-198.

28. Cantin, A.M., Hubbard, R.C., and Crystal, R.G. 1989. Glutathione deficiency in the epithelial lining fluid of the lower respiratory tract in idiopathic pulmonary fibrosis. Am. Rev. Respir. Dis. 139:370-372.

29. Kono, Y., and Fridovich, I. 1982. Superoxide radical inhibits catalase. J. Biol. Chem. 10:5751-5754.

30. Metodiewa, D., and Dunford, H.B. 1989. The reactions of horseradish peroxidase, lactoperoxidase, and myeloperoxidase with enzymatically generated superoxide. Arch. Biochem. Biophys. 272:245-253.

31. Ho, Y.S., et al. 1997. Mice deficient in cellular glutathione peroxidase develop normally and show no increased sensitivity to hyperoxia. J. Biol. Chem. 272:16644-16651.

32. Canada, A.T., Herman, L.A., and Young, S.L. 1995. An age-related difference in hyperoxia lethality: role of lung antioxidant defense mechanisms. Am. J. Physiol. 268:L539-L545.

33. Clerch, L.B., and Massaro, D. 1993. Tolerance of rats to hyperoxia. Lung antioxidant enzyme gene expression. J. Clin. Invest. 91:499-508.

34. Marklund, S.L. 1984. Extracellular superoxide dismutase in human tissues and human cell lines. J. Clin. Invest. 74:1398-1403.

35. Huie, R.E., and Padmaja S. 1993. The reaction of $\mathrm{NO}$ with superoxide. Free Radic. Res. Commun. 18:195-199.

36. Vilar, R.E., et al. 1997. Nitric oxide degradation of heparin and heparan sulphate. Biochem. J. 324:473-479.

37. Liochev, S.I., and Fridovich, I. 1994. The role of $\mathrm{O}_{2}$ - in the production of HO in vitro and in vivo. Free Radic. Biol. Med. 16:29-33.

38. Liochev, S.I., and Fridovich, I. 1990. Vanadate-stimulated oxidation of $\mathrm{NAD}(\mathrm{P}) \mathrm{H}$ in the presence of biological membranes and other sources of $\mathrm{O}_{2-}$. Arch. Biochem. Biophys. 279:1-7.

39. Grisham, M.B. 1994. Oxidants and free radicals in inflammatory bowel disease. 344:859-861.

40. Brown, D.M., Brown, G.M., Macnee, W., and Donaldson, K. 1992. Activated human peripheral blood neutrophils produce epithelial injury and fibronectin breakdown in vitro. Inflammation. 16:21-30.

41. Kubo, K., King, L.S., Kobayashi, T., and Newman, J.H. 1992. Differing effects of nitrogen mustard and hydroxyurea on lung $\mathrm{O} 2$ toxicity in adult sheep. Am. Rev. Respir. Dis. 145:13-18.

42. Smith, L.J., Friedman, H., and Anderson, J. 1988. Hyperoxic lung injury 
in mice: effect of neutrophil depletion and food deprivation. J. Lab. Clin. Med. 111:449-458.

43. Khan, S., Ramwani, J.J., and O'Brien, P.J. 1992. Hepatocyte toxicity of mechlorethamine and other alkylating anticancer drugs. Role of lipid peroxidation. Biochem. Pharmacol. 43:1963-1967.

44. Chernoff, A.E., et al. 1995. A randomized, controlled trial of IL-10 in humans. Inhibition of inflammatory cytokine production and immune responses. J. Immunol. 154:5492-5499.

45. Tsan, M.F., White, J.E., Michelsen, P.B., and Wong, G.H. 1995. Pulmonary $\mathrm{O} 2$ toxicity: role of endogenous tumor necrosis factor. Exp. Lung Res. 21:589-597.

46. Barazzone, C., Tacchini-Cottier, F., Vesin, C., Rochat, A.F., and Piguet, P.F. 1996. Hyperoxia induces platelet activation and lung sequestration: an event dependent on tumor necrosis factor-alpha and CD11a. Am.J. Respir. Cell Mol. Biol. 15:107-114.

47. Visner, G.A., Chesrown, S.E., Monnier, J., Ryan, U.S., and Nick, H.S. 1992.
Regulation of manganese superoxide dismutase: IL-1 and TNF induction in pulmonary artery and microvascular endothelial cells. Biochem. Biophys. Res. Commun. 188:453-462.

48. Lee, C.Y., Pastore, J.N., Tang, G., and Tsan, M.F. 1994. Cellular distribution of pulmonary $\mathrm{Mn}$ and $\mathrm{CuZn}$ superoxide dismutase: effect of hyperoxia and interleukin-1. J. Histochem. Cytochem. 42:1201-1205.

49. Welty, S.E., et al. 1993. Increases in lung tissue expression of intercellular adhesion molecule- 1 are associated with hyperoxic lung injury and inflammation in mice. Am. J. Respir. Cell Mol. Biol. 9:393-400.

50. Smith, C.W., et al. 1991. Adherence of neutrophils to canine cardiac myocytes in vitro is dependent on intercellular adhesion molecule-1. J. Clin. Invest. 88:1216-1223.

51. Fujita, H., Morita, I., and Murota S. 1994. A possible mechanism for vascular endothelial cell injury elicited by activated leukocytes: a significant involvement of adhesion molecules, CD11/CD18, and ICAM-1. Arch. Biochem. Biophys. 309:62-69. 